\title{
The international Challenges and Finnish Corporate Taxation ${ }_{1}$
}

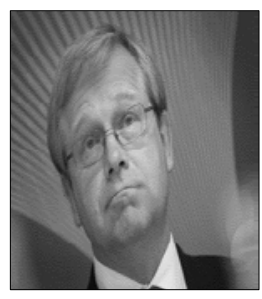

Juha Lindgren

Professor

University of Vaasa

Abstract: One of the main trends in Finnish corporate taxation during the last ten years has been the lowering of the corporate tax rate. The decision to lower the corporate tax rate to $20 \%$ from the beginning of 2014 also changed the approach in reforming the corporate taxation as it was decided to stay on the grounds of a broad tax base and not to make loopholes in it with targeted exceptions.

The Finnish corporate taxation contains also some provisions that act as incentives for investment and the establishment of companies. However, the focus has been lately on the rules with purpose to protect the national tax base. Therefore, article handles both the specific anti avoidance rules and the application of the general anti avoidance rule on the cross-border transactions. Some particular challenges and the exchange of information are also taken into account before the conclusion with some ideas and aspects on future reforms.

Keywords: Corporate taxation, incentives of investment and the establishment of companies, protection of tax base, general and specific anti avoidance rules.

\section{The Development of the Corporate Tax Rate}

One of the main trends in Finnish corporate taxation during the last ten years has been the lowering of the corporate tax rate. Since the re-

1 I would like to thank some of the leading experts for informative discussions on questions handled in the text. A list of references used both in English and Finnish is added at the end of this article. For those wishing to learn more about the subject in English I would especially point out "Finnish International Taxation" by Professor Marjaana Helminen. 
form of the Finnish Tax system in 1993, the corporate tax rate followed the flat tax rate on capital income of individuals. In the beginning of that period the level was $25 \%$ but it hit its peak during the years 2000 2004 at the level of $29 \%$. An important factor which tied those two closely together was the avoir fiscal system (Act on Imputation credit, YHL) which was implemented in Finnish legislation already in 1990 and survived until 2004. After that connection was abolished, the corporate tax rate has gradually gone down to $20 \%$ (2014). Meanwhile, the tax rate on capital income has risen to 30\% and, in 2014, capital income exceeding 40000 euros is taxed by $32 \%$.

\section{Formal corporate tax rate}

$\begin{array}{lll}\circ & 25 \% & 1993-1995 \\ \circ & 28 \% & 1996-1999 \\ \circ & 29 \% & 2000-2004 \\ \circ & 26 \% & 2005-2011 \\ \circ & 24,5 \% & 2012-2013 \\ \circ & 20 \% & 2014\end{array}$

This latest development is firmly based on the Final Report of the Working Group for Developing the Finnish Tax System (51/2010). The working group proposed, with respect to corporate and capital income taxation, a modest shift from corporate income taxation to personal-level capital income taxation. The working group also considered that the revenue share of corporate income tax should be transferred from municipalities to the central government and that the significance of real-estate tax for municipal finances should be increased. Due to the economic situation and the major changes planned on the number of municipalities and their responsibilities, the transfer of the revenue share from municipalities to the central government has not taken place yet.

The decision to lower the corporate tax rate from the beginning of 2014 also changed the approach in reforming the corporate taxation. Just a year before in 2013, several new or once again tried elements had been introduced to the Finnish business taxation. The per centage rate for depreciation on production investments was doubled for years 2013-2015 (it was increased also in 2009 and 2010). A special deduction for $\mathrm{R} \& \mathrm{D}$ costs doubled the amount of the deduction allowed on for example wages for years 2013-2015. Similar targeted, fixed term provisions were set also for some other interests to boost the economic growth. When the decision was made to lower the corporate tax rate to $20 \%$, the lifespan of the mentioned depreciation and deduction provisions was cut to two years i.e. 2013-2014 only. At the same time, 
well-prepared plans to implement patent box provisions in the Finnish tax system were given up. By these changes the government proposed and the parliament decided to stay on the grounds of a broad tax base and not to make loopholes in it with targeted exceptions.

\section{Rules that act as incentives for investment}

Although, under certain circumstances, Finnish source dividends may be tax-exempt also in cross-border situations, the benefits are equal with comparable situations between two Finnish companies. According to the Act on the Taxation of Nonresidents' Income (LähdeVL), the direct investment dividends paid by a Finnish company to a corporate entity in another EU member state are tax-exempt in Finland if the dividends fall within the scope of the Parent-Subsidiary Directive. The dividends paid to a company resident in an EEA country can be tax-exempt as they would be tax exempt if they were paid from one comparable Finnish company to another. These provisions include requirements on exchange of information and limitations on withholding tax not to be completely credited in the recipient's state of residence. In principle it is the question of national incentive which covers also these international situations. The direct investment dividends as well as certain sales of shares which belong to fixed business assets fall within the scope of so called participation exemption.

There are also alternatives where Finnish-source dividends paid to a foreign corporate entity can be subject to withholding tax. The lowering of the corporate tax rate has also had an effect on these provisions from the beginning of 2014. For this, see for example LähdeVL Sec. 7(1)3, the withholding tax of 18,38\% in 2013 (equals to $75 \% \mathrm{x}$ $24,5 \%$ ) has fallen to $15 \%$ in 2014 (equals to $75 \%$ x $20 \%$ ).

The taxation of Finnish-source interest of non-residents is usually different from the taxation on interest income of a resident. The interest income of a resident company is taxed as profit by a corporate tax rate $(20 \%)$ or as capital income of an individual. The tax rate on capital income is $30 \%$ and if the capital income exceeds 40000 euros it will be taxed by $32 \%$. The Finnish-source interest income can be tax-exempt for a non-resident for several reasons (the provisions of the LähdeVL, the Interest-Royalty Directive and the Savings Directive). Therefore it can be said that taxation of interest income is not neutral. In aggressive tax planning this might cause arrangements where Finnishsource income is collected to a foreign company. Only applying the Finnish CFC rules on the recipient company would make that kind of interest income taxable in Finland. 
The articles of tax treaties on both dividends and interests have an effect on the taxation of cross-border situations. The concept of beneficial owner has not been widely adapted in Finnish tax law as such but the question of directing the taxation to a right tax payer receiving the income is solved either according to the provisions of law or the articles of the tax treaty. A detailed analysis of withholding tax questions would require a report of its own. Therefore the scope of this presentation is on a general level based on certain examples.

\section{Rules that act as incentives for the establishment of companies}

Rules that act as incentives for the establishment of companies have not been used often in Finnish tax legislation. An exception can be found in the reform of the Finnish tax system which came mostly into force at the beginning of 2005. These provisions were motivated to a great extent by the globalized economy and the threat caused by international tax competition. Similar systems of tax-exempt alienation of shares had been formed in several European countries and in the government proposal $(92 / 2004)$ the arguments for why the Finnish system had to follow were well validated.

According to EVL (Business Income Tax Act) Secs. 6(1)1 and 6 b, the sale of shares of a company may be tax-exempt for a Finnish corporate entity when certain conditions are applicable. The Finnish resident alienator must have held at least $10 \%$ of the capital in the company for at least a year. The shares must belong to the fixed business assets of the Finnish alienator. The company whose shares are sold must not be a real-estate company. Besides to the sale of the shares of the Finnish resident company, the amendments also apply to alienation of the shares of the foreign company if it would qualify for the benefits of the EC Parent-Subsidiary Directive or if Finland has concluded a tax treaty eliminating double taxation with the foreign company's state of residence. The reform also included rules to limit the deductibility of losses of alienation and certain expenses that might have an effect on the tax exempt sale of the shares. It also had some other effects on the tax system.

These provisions set an example of an incentive, its limits and its effect on the Finnish tax system. Originally, the change was motivated in the government proposal by threat of international tax competition and changes that had been made in other countries. The requirement of $10 \%$ ownership was set on the level of direct investment familiar from the international tax law and practice where the corresponding level can be found both on dividends and sale of shares. So the do- 
mestic law offered similar results in tax planning as some more complicated international arrangements. The other requirements, however, restrict the application on the provisions in many ways. Therefore the provisions can be seen as complicated and to leave room for judicial interpretation. On the other hand, the possibility of tax-exempt sale of shares within the system of a broad tax base can be considered as a very tempting alternative which has increased the number of arrangements focusing on the application of these provisions.

Nevertheless, several problems have occurred in the interpretation of these provisions and have given rise to many case-law decisions. These decisions mainly concern domestic arrangements. Therefore it's quite justified to ask whether the strict requirements and the lack of predictability of interpretation have had other -or even opposite- effect than was originally targeted as an incentive on international level. These doubts have echoed even louder when Finnish provisions have been compared to corresponding provisions in the Swedish tax system. To conclude, the sale of shares of a resident company is also subject to a transfer tax of $1,6 \%$ if either party of the transfer is resident in Finland (Transfer Tax Act, VsVL).

\section{Rules with purpose to protect the national tax base}

The need to protect the national tax base has become an even greater issue for countries trying to handle the challenges of their economy and public debt. Also in Finnish government proposals we can see the changes motivated as ways of tackling tax avoidance and evasion arrangements and trying to adjust to international tax competition. They do have an effect on the Finnish economy, legislation, and tax system. These factors can be found in the government proposals for example on changes to CFC rules, transfer pricing rules as well as on introducing interest deduction limitation rules to the Finnish tax system.

\subsection{Controlled foreign company (CFC) rules}

The special controlled foreign company (CFC) regime, the Act on the Taxation of Shareholders in Controlled Foreign Corporate Entities (VYL, 1217/94) came into force at the beginning of 1995. It may apply if one or more Finnish residents control a foreign corporate entity registered in a low-tax state. According to VYL, a resident shareholder with a share in a controlled foreign company is liable to pay tax on his share in the CFC's income if certain conditions are met.

During the last decade the change of some of these conditions was triggered by the decision made on 12 September 2006 by EU Court C196-04 (Cadbury Schweppes). Although it concerned the CFC rules of 
the UK, the case clearly brought up the contradiction between the Finnish CFC regime and the EC Treaty and the EEA Agreement principle of the freedom of establishment. The changes that came into force in 2009 (680/2008) then also covered several aspects of the CFC rules that had been found problematic or open to various interpretations.

According to VYL Sec. 2, a resident entity of an EU, EFTA or a tax treaty state falls outside the scope of CFC treatment when the following conditions are met:

- $\quad$ the exchange of information in tax matters between the states' administrations is arranged sufficiently,

- the entity is actually established in its state of residence and

- the entity carries out genuine economic activities in that state.

The provisions were clarified and changed from the beginning of 2009 as regards

- $\quad$ foreign permanent establishment comparable to CFC under certain conditions, VYL 2(2), (PE that existed already on 31.12.2007 will be treated as CFC only from the beginning of 2015)

- the limit of tax liability; proportional ownership or beneficiary position of Finnish corporate entity or individual grew from $10 \%$ to $25 \%$, VYL 4 ,

- $\quad$ CFC income; income type VYL 4(3), losses VYL 5, foreign tax credit VYL 6 (A carry forward was lengthened to five years from the beginning of 2010, 1361/09)

The decisions of the Supreme Administrative Court after the changes to the scope of the CFC rules have concerned countries like Singapore (not treated as a controlled foreign company according to $\mathrm{KHO}$ 2011:42) and Hongkong (treated as a controlled foreign company according to KHO 2012:118 because the planned production was to be established in continental China instead of Hongkong).

Because of the change of corporate tax rate in Finland 2014, the CFC conditions can now only apply to countries with an actual rate of income tax for CFC less than $12 \%$ (3/5 of the tax rate of a corporate body resident in Finland).

\subsection{Transfer pricing rules}

The current provisions concerning the arm's length principle and the required documentation apply since the beginning of 2007. In "Taxation in Finland 2009" (Ministry of Finance publication, VM 7/2009) the new provisions were described as follows. According to VML Sec. 
31 (Act on the Assessment Procedure), if in a transaction between a taxpayer and a related party, these parties have agreed on terms or imposed terms which differ from those which would have been agreed upon between independent parties, and for this reason the taxpayer's business profits or income from other activity remain smaller or the taxpayer's loss becomes bigger than they would otherwise have been, the income is increased by the amount that would have been accrued when the terms had corresponded to what would have been agreed on between independent parties. The principle applies also to transactions between enterprise and its permanent establishment. Provisions include the amendments of the situations when parties to a transaction are related in a way that a party has control of other party.

According to provisions in VML Secs. 14 a-14 c concerning the written documentation on annual transactions with related parties with some limitations, the following information must be given: 1) description of the business; 2) description of all associated relationships; 3) information on transactions between associated parties and between an enterprise and its permanent establishment; 4) functional analysis of all transactions mentioned in 3); 5) comparability analysis including the available information on points of comparison; 6) description of the transfer pricing method and its application. Provisions also include requirements on when the documentation must be presented to the tax authorities. From the beginning of 2007 came into force also VML Sec. 32(4) on administrative fine if a taxpayer neglects to give the documentation on annual transactions with associated parties. According to the provision the maximum fine is 25000 euros.

According to the government proposal $(107 / 2006)$ on the changes described above the new legislation wasn't supposed to cause any immediate need for increasing the number of staff at the Tax Administration but that there might be a need for some resource reallocation. It wasn't until the beginning of 2012 that all nationwide transfer pricing tasks were centralized to a three-year Transfer Pricing Program, which is located in the Large Taxpayers' Office. In the first year 2012, transfer pricing adjustments to the taxable income totaled 298 million euros and 2013 the amount was 892 million euros.

It has been obvious that these adjustments will bring about a lot of questions about the interpretation of domestic law, the OECD Transfer Guidelines, tax treaties etc. Also the methods of Tax Administration, the Transfer Pricing Program and tax audits have been inquired about. Because listed companies have strict rules on how to inform about this type of adjustments, some of the cases have been in the media. The Supreme Administrative Court $(\mathrm{KHO})$ has given a decision KHO 2014:119 on 3rd of July 2014 on a case concerning a hybrid 
loan to a Finnish limited liability company from its main owner based in Luxembourg. According to KHO the loan could not be treated as equity instrument in taxation based on VML Sec. 31and therefore the interest was tax deductible. The re-characterization issues are handled also in the next chapter: general anti avoidance rules. The Supreme Administrative Court has given a decision KHO 2014:33 on a transfer pricing issue related to valuation of shares sold within a group of companies. Many of the recent KHO decisions are still from the time before the Transfer Pricing Program.

In the BEPS action plan, OECD has pointed out that a lot of effort should be put on transfer pricing issues and also on tightening the CFC rules. On the other hand both OECD and the EU Commission have shown their support for the acceptance of a general anti avoidance rules.

\subsection{General anti avoidance rules}

Finland has a long tradition on applying general anti avoidance rules / provisions. The origins of the provisions can be traced back to the 1930's. The most recent provision in the Act on the Assessment Procedure (VML), Sec. 28, allows the Finnish tax authorities or courts to re-characterize any transaction and to tax, based on the true nature of the arrangement irrespective to its legal form. According to the provision, if a transaction has been assigned a legal form which does not correspond with its actual character and meaning, taxation should take place as if the correct form had been adopted. In addition, it must be evident that the transaction has been entered into in order to avoid Finnish tax.

The provision VML Sec. 28(2) states explicitly that the provision may only be applied if the taxpayer cannot prove that the form of transactions corresponds to its substance, or that the real purpose of the transactions was not to avoid taxes. Therefore the general anti avoidance provision cannot be applied if genuine business reasons for the transactions are shown.

Even though according to the Finnish Constitution, taxes must always be based on law, the nature and role of the VML Sec. 28 has seldom been questioned as a part of the Finnish tax system. On the contrary, concerning the application of the general anti avoidance provision there is a lot of case-law dealing mainly with domestic situations. So it seems that the general provision leaves to a considerable extent room for judicial interpretation. The wide variety of decisions of $\mathrm{KHO}$ (Supreme Administrative Court) covers the interpretation on most of the questions that have arisen so far.

On cross-border arrangements, the EU law restricts the application of the provision. The EU law requires that the transaction should be 
regarded as a "wholly artificial arrangement" as characterized by EU Court in C-196-04 (Cadbury Schweppes). The effect of these EU Court cases has a strong impact on the Finnish provisions aiming especially to protect the tax base in cross border situations such as CFC rules. These EU Court cases have also initiated some changes in Finnish provisions. Another example on a special provision is the EU Merger Directive's provision which was implemented into EVL (Business Income Tax Act) Sec $52 \mathrm{~h}$. Nevertheless, the general anti avoidance rule still seems to have effect and it could also be applicable on crossborder arrangements in the EU tax regime.

Another perspective to the application of a general anti avoidance provision is when it is applied together with another provision such as the special profit adjustment provision in VML Sec. 31. An example of this would be if an intra-group transaction(s) includes a clear tax avoidance purpose. The application of both of these provisions may make it possible for Finland to tax such profits in a transfer pricing situation which a special profit adjustment provision alone would not cover.

This framing of the question leads us to a very up-to-date debate related to Finnish tax law. The question has been whether, under certain circumstances, an intra-group loan should be treated as a loan or rather be re-characterized as a contribution to equity capital in taxation. And furthermore, can the adjustment and re-characterization made by a tax authority be based on the application of the special profit adjustment provision, VML Sec. 31 alone. The Supreme Administrative Court (KHO) gave a decision KHO 2014:119 on $3^{\text {rd }}$ of July 2014 on related question. According to KHO VML Sec. 31 did not contain a specific rule which re-characterization of the transaction would have required. Therefore the application of the general anti avoidance provision, VML Sec. 28, would have been needed.

\subsection{Interest deduction limitation}

In Finland, the thin capitalization rules have been mentioned in some working group memorandums and government proposals. The Ministry of Finance did not take the action and give a proposal in order to take thin capitalization rules as a part of Finnish Tax system. Instead, provisions on interest deduction limitation were added to the Finnish tax system. This fact has had an effect on the argumentation in the debate on re-characterization issues in transfer pricing.

The right of corporate bodies, general partnerships and limited partnerships to deduct interest expenses is limited in business taxation from the beginning of 2014. According to a Ministry of Finance the aim was to safeguard the tax base in Finland and to discourage tax 
planning of companies where the group's interest is directed to jurisdictions with low taxation.

According to this new provision EVL (Business Income Tax Act) Sec. 18 a (28.12.2012/983), interest expenses can be deducted in full to a sum equivalent to interest income. Where net interest expenses, meaning interest expenses that exceed interest income, are no more than 500,000 euros, they can be deducted in full.

Interest expenses exceeding 500,000 euros are tax deductible to the amount corresponding to at most $25 \%$ of the business income tax result. Net interest expenses exceeding the $25 \%$ amount are non-tax deductible. However, the sum of non-tax deductible interest expenses based of the $25 \%$ limit is at the most an amount corresponding to intra-group net interest expenses. The deductible per centage was originally $30 \%$ but the interest deduction limitation rules were slightly tightened, as the maximum amount of deductible interest was reduced from 30 per cent to 25 per cent and the losses and changes in the value of financial assets were removed from the items that are added in the calculation base of the per centage share. These changes were made in 2013 and they came into force at the beginning of 2014 when the provisions were applied for the first time.

According to the Ministry of Finance, the restriction of the right to deduct interest expenses is a general restriction. It applies to both domestic and foreign corporate bodies and partnerships, and is imposed on both national and cross-border interest payments. Where a business provides documentation that the ratio of equity to the financial accounts balance sheet total is higher or equal to the same ratio in the confirmed group balance sheet, the restriction on the right to deduct interest expenses is not imposed.

It is possible to make an appeal on non-tax deductible net interest expenses for the fiscal year to which the decision on non-tax deductible net interest expenses pertains. The Finnish Central Tax Board (KVL) has already given several published decisions (KVL 25/2013, $63 / 2013,4 / 2014,6 / 2014$ and 10/2014) on the interpretation of interest deduction limitation rules. The appeals have, among other things, handled the questions relating to the interpretation of the ratios mentioned and how the ratio in the confirmed group balance sheet is defined in practice. Only a couple of these published decisions have become final or have been decided by KHO (The Supreme Administrative Court) by the time this article is written.

Interest deduction limitation rules do not apply to credit institutions or insurance and welfare institutions or, to a certain extent, to their affiliated bodies. Non-tax deductible net interest expenses can be deducted from taxable income of successive fiscal years within the yearly limits of tax-deductible interest expenses. 


\subsection{The exit tax rules}

According to EVL Sec. 51 e, if a foreign company sells its business property which belongs to its Finnish permanent establishment, the realized capital gains are included in the taxable profits of the PE in Finland. The taxable amount realized by the sale is calculated by deducting the book value from the current value. The tax treatment will be alike according to the amendment mentioned, if the Finnish permanent establishment is closed down and its business property is transferred to another part of the company in another country. Also transferring a part of the business property of the Finnish PE to another part of the company elsewhere without closing down the Finnish PE will lead to a similar taxation of the transferred property.

In principle, according to Finnish tax legislation, assets can be transferred from Finland only by using their current value. The idea is expressed in provisions such as EVL Secs. 51 e and 52 e and Act on Assessment Procedure, VML Sec. 31.

According to EU Court decisions, EVL Sec. 51 e is somewhat questionable from the perspective of the freedom rights in EU (esp. free movement of capital and freedom of establishment). This question arises when assets are transferred to another EU Member State or another state within EEA. The Administrative Court of Helsinki expressed in its decision (Helsingin HAO 6.6.2013 13/0910/4) that the application of EVL Sec. 51 e had resulted in a tax treatment which is in contradiction with several EU Court decisions (for example 29.11.2011 C-371/10, National Gris Indus BV and 6.9.2012 C-38/10, European Commission vs. Portugal). The HAO decision brings up this interesting question also in Finland. The decision is not final because it has been appealed to the Supreme Administrative Court.

The expert working group on business taxation concluded in their memorandum $(16 / 2013)$ that the starting point in Finnish tax law could be that an entity liable to tax could choose whether it would pay the exit tax right away or whether it would apply for delayed payment of exit tax. It also proposed that the entity liable to tax should set a security for the delayed tax payment and it should pay interest for the time of delay. The expert working group also stated that the option of delayed payment could also be limited to arrangements where the assets are transferred within EEA. So far these ideas of the expert working group of business taxation have not lead to government proposals in order to make these changes in Finnish legislation.

It is also possible that a Finnish permanent establishment is transformed into a subsidiary company of a company situated abroad. If the arrangement involves only EU Member State resident companies, the Finnish provisions in EVL Secs. 52 d-52 e may apply to this crossborder transfer of assets and it will not give rise to any taxable in- 
come. If these special provisions don't apply to a transformation described above, the current price of the transferred assets is treated as taxable profit. According to EVL Sec. $52 \mathrm{e}$, if the assets do not remain in the Finnish permanent establishment, the arrangement realizes the current value of transferred assets as taxable profits.

Also in the case of cross-border mergers and divisions, the provisions in EVL Secs. 52-52 e apply if the companies involved are residents of EU Member States and if the transferred assets remain as the business property of the permanent establishment which is established by the arrangement. If the assets do not remain in the Finnish permanent establishment, the arrangement realizes the current value of transferred assets as taxable profits.

The Finnish Central Tax Board (KVL) has recently given two decisions (KVL 15/2013 and KVL 26/2013) on a Finnish investment fund merging to a foreign investment fund (Swedish and Luxembourgian, respectively). By the KVL's decision, the EVL Secs. 52 a-52 b was applicable to both arrangements even though after the arrangement there was no Finnish permanent establishment in which the funds of the merging Finnish investment fund would have been located. KVL's argumentation mentioned, among other things, the taxable status of the investment funds after the merger and their nature as a mass of assets. This interpretation and its possible contradiction with the amendment of EVL Sec. 52 e will be decided by the Supreme Administrative Court because there is an appeal on the case KVL 26/2013 (investment fund, Luxembourg).

Otherwise the use of specific exit taxes is not very frequent in the Finnish system. The latest examples relate to the exchange of shares according to EVL Sec. $52 \mathrm{f}$ (Business Income Tax Act) and TVL Sec. 45 (Income Tax Act). According to the amendment, the tax benefit is lost if the taxpayer becomes a non-resident for the Finnish domestic law or tax treaty purposes and becomes a resident in a country outside of EEA within five years from the end of the tax year in which the exchange took place. The exempted amount is taxable income of the year during which the taxpayer moved to a country outside EEA.

\section{Particular challenges}

As described, Finland has set its formal tax rate a little below the average in Nordic comparison. From tax competition's point of view, however, the Estonian system and tax rate in corporate taxation can be seen as tempting compared to the Finnish rate. According to the Estonian embassy (www.estemb.fi), the number of Finnish-owned businesses in Estonia is over 4,700. The interest has been growing and 
the number rose by over 500 businesses in 2011. These businesses are estimated to be mostly relatively small but their number might show a trend. It would be much more difficult to document the effect that the Estonian business environment has on foreign corporate entities seeking location, whether they end up coming to Estonia instead of Finland.

Another concern in cross-border activities has been the great number of Estonian workers and businesses that have been active in Finland especially in certain branches of business such as the construction industry for several years. The registration and identification rules related to personal taxation have been recently reformed and have an effect also on foreign construction workers. In addition, the question of permanent establishment has risen among the Estonian as well as other foreign businesses active in Finland. The Finnish Tax Administration has shown a growing interest in clarifying the situation and registering foreign businesses where the conditions of permanent establishment have been fulfilled.

After two years of experience from the "Transfer Pricing Program", an "International Taxation Risk Program" was launched by the Finnish Tax Administration in January 2014 to tackle the risks of different types of international phenomena. The aim is to diminish the tax gap related to the international risks of tax evasion. The program can be seen as a first phase to plan and start the actual work and it will last until the end of 2015. Although the agenda and timetable are not connected to BEPS Action Plan, the idea is to cover some of the areas in the projects within the program.

As expressed in the Report "Addressing Base Erosion and Profit Shifting", OECD called on governments to identify and address areas leading to opportunities for BEPS. The challenge is "if governments are not happy with the results under the laws, they must change the laws".

\section{An example of the political agenda in Finland}

The program of the Finnish government (22.6.2011) includes ideas on safeguarding and broadening the tax base. Former Minister of Finance, Jutta Urpilainen wanted to take an active role in the combat against tax evasion. The Finnish Ministry of Finance and the Finnish Parliament organized an international event on "STRENGTHENING THE FIGHT AGAINST TAX FRAUD AND TAX EVASION; STATE OF PLAY AND THE WAY FORWARD" in Helsinki, 29th April 2013. According to Minister Urpilainen, the focus of the meeting was to turn the momentum of recent development into action against tax ha- 
vens, tax evasion and aggressive tax planning. She brought up among other issues that "In Finland, I have initiated ... closer follow-up on transfer pricing, which has already during the first year increased revenues with 80 million euros".

She wanted to raise three concerns to be tackled: bank secrecy, corporate secrecy as well as the secrecy between states, which mean that to grasp the problem of tax evasion, more information exchange is needed.

On bank secrecy the main topics were FATCA, automatic exchange of information between any two countries and a closer EU coordination of these initiatives as well as the national level actions in order to force banks to inform authorities about big transfers to foreign accounts. On corporate secrecy she brought up, among other things, the need for more open registers of companies to gain knowledge on the ownership of companies in order to avoid tax evasion, and the challenge of the artificial arrangements of multinational companies to avoid taxes.

The main focus was on secrecy between states and the problem of Tax Information Exchange Agreements (TIEAs) being used for exchange of information on request when OECD should be supported in its efforts for a global standard in automatic information exchange. Minister Urpilainen also mentioned the need of agreement on minimum standards for a country not to be listed as a tax haven and the need of naming and shaming on the black listed tax havens to put pressure on those countries that do not participate in the tax information exchange properly. Among the participants and panelists were commissioner Algirdas Semeta, Director of CTPA (OECD) Pascal Saint-Amans and Ministers of Finance of several European countries.

\section{The OECD report on exchange of information in Finland}

Like all the Nordic countries, Finland has a longstanding involvement in international exchange of information in tax matters. According to OECD Global Forum of Transparency and Exchange of Information for Tax Purposes - Peer Review Report (28 February 2013), Finland was able to exchange information in tax matters through a broad network of EOI arrangements covering 119 jurisdictions. Out of these 119 jurisdictions 110 were DTCs (71) and TIEAs (39), and 95 of them were in force at the time of the report. Remaining nine jurisdictions were parties only to the Multinational Convention and / or the Nordic Mutual Assistance Convention on Mutual Administrative Assistance in Tax Matters. Finland was also one of the first countries to sign and rat- 
ify the Multilateral Convention and the 2010 protocol which came into force on the $1^{\text {st }}$ June 2011. According to the report, Finland's EOI arrangements covered all its relevant partners including major trading partners as well the EU and the OECD member jurisdictions.

These results encourage Finland to continue the work in order to improve especially the automatic exchange of information. The tax administrations of Nordic countries have all been active in this work. Report inputs from Finland's peers suggested that Finland's practices in terms of exchange of information were of a very high standard and they consider Finland to be reliable, efficient and cooperative exchange of information partner.

\section{Some Ideas and Aspects on Future Reforms}

The Ministry of Finance appointed on the 20 2 th December 2011 an expert working group on business taxation to prepare a report on the reform of business taxation in order to safeguard competitiveness and the tax base. In the field of structural reforms, the working group was expected to examine the reform of the group taxation system and the possibility of abolishing income basket division. In the field of issues relating to the international transfer of profits and safeguarding the tax base, the working group assessed the limitation of interest deductibility, the determination of tax residence of undertakings and the exit from Finland's taxing power.

In the memorandum (Ministry of Finance publications, VM 16/2013) the expert working group proposed that the preparation of the group taxation system be continued, primarily on the basis of a joint taxation model for groups. The development of legislation within the EU and EU Member States should also be taken into account in further preparation and in selecting the system.

With respect to income basket division, the working group considered that all of a limited company's activity carried out for the purpose of obtaining income should be taxed as a single basket of income on consistent criteria in accordance with the Act on Taxation of Business Income. Further preparation should assess the form in which the reform should be implemented and how the issue in terms of other types of undertakings should be enacted.

The working group considered a general undertakings' interest limitation rule as more appropriate that a specific rule. Interest limitation rule came into force on $1^{\text {st }}$ of January 2013 and it was applied for the first time in taxation performed for 2014. According to the working group's proposal, the interest limitation rule should be imple- 
mented in Income Tax Act (TVL) and this should be considered in further preparation of income basket division.

In addition, the working group proposed that the tax residence of an undertaking would also be determined on the basis of the place of effective management. The proposal would safeguard the tax base and even expand Finland's taxing power in tax treaty interpretation. Therefore the territorial taxing power of Finland would have the same basis as many other countries and it would fit better in determining the residence of an undertaking. When Finland is considered to be the country of residence, the corporate entity is normally liable to tax on a wider variety of income. Non-resident corporate bodies are liable to tax on their income derived from Finland. If a foreign corporate body has a permanent establishment in Finland, the corporate body is liable to tax for all income attributable to that permanent establishment.

The memorandum of the expert working group on business taxation was published in June 2013. As mentioned, all areas covered will need further preparation in order to get the changes made. The memorandum can be seen as a good starting point for development of the Finnish system. The importance of national work becomes even greater as international proposals for improvement - such as CCCTB don't seem to get the support needed. 


\section{List of references}

\section{In English}

Helminen, Marjaana (2009), Finnish International Taxation. 2nd edition. Edita. VM 7/2009. Taxation in Finland.

\section{In Finnish}

Andersson, Edward - Ikkala, Jarmo - Penttilä, Seppo (2009), Elinkeinoverolain kommentaari. 12. uudistettu painos. Talentum.

Helminen, Marjaana (2012), EU-vero-oikeus - välitön verotus. 2. painos. Talentum

Helminen, Marjaana (2013), Kansainvälinen tuloverotus. 2. painos. Edita.

Helminen, Marjaana (2014), Mahdollistaako VML 31 \& etuyhteyslainan uudelleenluokittelun ilman VML 28 §:n tukea? Defensor Legis N:o 1/2014, s. 85-96.

Isomaa-Myllymäki, Anita (2014), Konsernin sisäisen rahoituksen markkinaehtoisuus: Rahoitusrakenne ja uudelleenluokittelu. Verotus 1/2014 s. 72-85.

Juusela, Janne (2013), Suomen verojärjestelmän kilpailukyvystä. Minne menet vero-oikeus? Juhlajulkaisu Raimo Immoselle. Turun kauppakorkeakoulun julkaisuja, sarja C, s. 39-50.

Karhu, Einari (2009), Väliyhteisölaki muutosten edessä. Verotus 2/2009 s. 175186.

Keinonen, Markku (2013), Kansainvälinen yhteisöverokilpailu jatkuu kansallinen verostrategia ja veropohjan puolustaminen. Verotus 4/2013, s. 401-417.

Malmgren, Marianne (2008), Oikeushenkilön asuinvaltio verotuksessa ja yrityksen kansainvälistyminen, Edita

Malmgren, Marianne (2009), Osinkotulojen lähdeverotuksen muutokset. Verotus 2/2009 s. 157-166.

Myrsky, Matti - Malmgren, Marianne (2014), Elinkeinotulon verotus. 4. uudistettu painos. Talentum.

Penttilä, Seppo (2007), Veron kiertäminen - EY-oikeudellisia näkökohtia. In memoriam Kari S. Tikka 1944-2006, Suomalainen lakimiesyhdistys, s. 324337.

VM 51/2010. Verotuksen kehittämistyöryhmän loppuraportti.

VM 16/2013. Elinkeinoverotuksen asiantuntijatyöryhmän muistio. 